\title{
HAK ATAS KEKAYAAN INTELEKTUAL DALAM DUNIA INDUSTRI PERDAGANGAN
}

\author{
Firdia Riani \\ 155100033, 785567851 \\ Fakultas Komputer \\ Firdiariani.student@umitra.ac.id
}

\begin{abstract}
Hak kekayaan industri adalah hak yang mengatur segala sesuatu milik perindustrian, terutama yang mengatur perlindungan hukum. Hak kekayaan industri sangat penting untuk didaftarkan oleh perusahaan-perusahaan karena hal ini sangat berguna untuk melindungi kegiatan industri perusahaan dari hal-hal yang sifatnya menghancurkan seperti plagiatisme. Dengan di legalkan suatu industri dengan produk yang dihasilkan dengan begitu industri lain tidak bisa semudahnya untuk membuat produk yang sejenis/ benar-benar mirip dengan mudah. Dalam hak kekayaan industri salah satunya meliputi hak paten dan hak merek.
\end{abstract}

Kekayaan intelektual adalah kekayaan yang timbul dari kemampuan intelektual manusia yang dapat berupa karya baik di bidang teknologi, ilmu pengetahuan, seni maupun di bidang sastra. Karya ini dihasilkan atas kemampuan intelektual melalui pemikiran, daya cipta dan rasa yang memerlukan curahan tenaga, waktu dan biaya untuk memperoleh suatu "produk" baru dengan landasan kegiatan penelitian atau yang sejenis. Kekayaan Intelektual (HAKI) atau Hak Milik Intelektual (HMI) atau harta intelek (di Malaysia) merupakan padanan bahasa Inggris intellectual property right. Kata "intelektual" tercermin bahwa obyek kekayaan intelektual tersebut adalah kecerdasan daya pikir, atau produk pemikiran manusia (the creations of the human mind) (WIPO, 1988:3).

Dapat disimpulkan bahwa HaKI adalah bagian penting dalam penghargaan dalam suatu karya dalam ilmu pengetahuan, sastra maupun seni dengan menghargai hasil karya pencipta inovasi-inovasi tersebut agar dapat diterima dan tidak dijadikan suatu hal untuk menjatuhkan hasil karya seseorang serta berguna dalam pembentukan citra dalam suatu perusahaan atau industri dalam melaksanakan kegiatan perekonomian.

Kata Kunci: HaKI Perdagangang,Hukum Industri,perekonomian. 


\section{A. INTRODUCTION}

Pada era sekarang ini di mana industri kian berkembang dan kompetisi dagang antar industri yang menghasilkan produk serupa semakin tinggi, di situ kita setuju dengan istilah "may the best wins" (hanya yang terbaiklah yang akan unggul). Salah satu bukti bahwa suatu produk merupakan yg terbaik di bidangnya adalah dengan adanya pengakuan dari masyarakat atau kualitas suatu barang atau jasa tertentu atau "brand recognition". Pengakuan ini tidaklah semata-mata timbul, namun harus melalui proses panjang yang merupakan suatu kerja keras dari para stakeholder dengan berbagai strategi yang mereka miliki dengan disertai bukti berupa hasil nyata yang dapat diterima dan diakui oleh masyarakat. Strategi-strategi tersebut di antaranya meliputi inovasi-inovasi di bidang teknologi dalam menciptakan suatu inovasi produk, yaitu menciptakan produk yang belum pernah ada sebelumnya atau melengkapi / menyempurnakan produk yang telah ada. Inovasi sebagai sebuah strategi tersebut merupakan buah pemikiran atau bisa disebut sebagai suatu karya intelektual yang merupakan kekayaan intelektual (intellectual property) atau biasa disebut sebagai Hak Kekayaan Intelektual / HKI (Intellectual Property Right) yang harus dilindungi.

Perlindungan terhadap Hak Kekayaan Intelektual ini tidak lepas dari adanya upaya dari Pemerintah dalam menjamin perlindungan terhadap hak kekayaan intelektual tersebut melalui perangkat hukum yang kuat, di antaranya terdapat Undang-Undang No. 14 Tahun 2001 tentang Paten dan Undang-Undang No. 15 Tahun 2001 tentang Merek. Selain itu terdapat pula Undang-Undang lainnya yang mengatur tentang Rahasia Dagang ; Desain Tata Letak Sirkuit Terpadu ; Desain Industri dan UndangUndang Hak Cipta. Kuat di sini dalam arti memiliki "daya paksa" berupa sanksi pidana maupun perdata terhadap suatu pelanggaran. Kepastian hukum yang menjamin perlindungan atas aset-aset kekayaan intelektual akan merangsang industri-industri untuk terus mengembangkan diri 
melalui inovasi-inovasinya yang tentunya akan meramaikan pasar industri lokal dalam negeri untuk bersaing dengan produk-produk dari luar negeri.

\section{Hak Kekayaan Intelektual (HKI)} secara esensial berbicara mengenai hak atas kekayaan yang lahir dari intelektual manusia. HKI memiliki 3 unsur penting yaitu hak, manusia dan intelektual. Dari ketiga unsur tersebut, maka terciptalah karya ciptaan. Untuk karya-karya ciptaan perlu mendapatkan perlindungan untuk mencegah pihak-pihak yang tidak bertanggungjawab untuk meniru, memperbanyak serta memperdagangkan karya ciptaan orang lain.

Hak Kekayaan Intelektual mencakup 2 kelompok yaitu Hak Cipta dan Hak Kekayaan Industri. Keduanya dilindungi dan diatur di dalam peraturan perundang-undangan yang berlaku dan barang siapa melanggarnya akan dikenai sanksi yang seberat-beratnya. Untuk itu kita wajib menghargai karya-karya ciptaan orang lain dan berusaha mengurangi pembelian-pembelian produk bajakan yang semakin marak sekarang ini.

Di Indonesia penerapan HaKI baru dapat dilakukan akhir-akhir ini, ini dikarenakan sudah mulai banyaknya kasus-kasus yang melibatkan kekayaan intelektual didalamnya, oleh karena itu maka pada tahun 2002 disahkanlah undang-undang tentang $\mathrm{HaKI}$, yang mengatur tata cara, pelaksanaan, dan penerapan HaKI di Indonesia. Dengan adanya UU HaKI,diharapkan dapat lebih mengatur tentang hak-hak seseorang terhadap karyanya, dan juga dapat menjerat pelaku kejahatan HaKI.

Sebelum terbentuknya Negara ini, Indonesia telah mengenal yang namanya hukum. Banyak dari nenek moyang kita yang hidup dengan aturan yang diatur di tempat mereka tinggal. Aturan seperti yang mengikat mereka, yang sekarang dikenal dengan istilah hukum. Menurut Plato, hukum merupakan peraturan-peraturan yang teratur dan tersusun baik yang mengikat masyarakat Berbicara mengenai hukum industry di Indonesia saat ini, pastilah sering kita temui beberapa pendapat yang saling 
bertentangan. Mulai dari hal yang sederhana sampai pada masalah yang cukup berat. Seperti info terbaru yang diperoleh yaitu mengenai tujuh perusahaan yang terjerat kasus hukum industri di Indonesia. Hukum industri merupakan suatu 'payung' yang berfungsi untuk melindungi suatu bidang industri yang ada. hal ini menyangkut sarana pembaharuan di bidang industri, sistem kawasan sebagai tata ruang, sistem perizinan yang bersifat lintas lembaga dan yurisdiksi hukum industri dalam perspektif global dan lokal, hukum alih teknologi. Hukum industri juga menyangkut permasalahan desain produksi dan hukum konstruksi serta standardisasi, tetapi juga mengenai masalah tanggungjawab dalam sistem hukum industri, dan analisis tentang masalah tanggung jawab dalam sistem hukum industri.

\section{B. CONTENT}

(Studi Kasus : Hukum Industri di Indonesia)

Hukum industri menyangkut sarana pembaharuan di bidang industri, sistem kawasan sebagai tata ruang, sistem perizinan yang bersifat lintas lembaga dan yurisdiksi hukum industri dalam perspektif global dan lokal, hukum alih teknologi. Hukum industri juga menyangkut permasalahan desain produksi dan hukum konstruksi serta standardisasi. Selain itu juga mengenai masalah tanggungjawab dalam sistem hukum industri, dan analisis tentang masalah tanggungjawab dalam sistem hukum industri.

Peraturan mengenai desain industri dapat dilihat pada Undang-Undang No. 31 tahun 2000 tentang desain industri. Hukum industri mengandung perlindungan bahwa hasil dari sebuah desain industri muncul dari adanya kemampuan, kreativitas cipta, rasa, dan karsa yang dimiliki oleh manusia. Hukum industri juga sangat bermanfaat untuk membatasi segala kemungkinan yang mungkin terjadi. Contohnya seperti terjadinya kerusakan alam dan ekosistem dunia. Keselamatan bagi konsumen, produsen, pekerja, dan lain-lain. Sebaik-baiknya suatu hukum adalah untuk dapat membatasi hal-hal yang 
dapat merugikan alam, manusia dan makhluk hidup lainnya.

Di indonesia Hukum Industri telah diatur dalam undang-undang perindustrian dan telah diterapkan dan menjadi sebuah persyaratan atau legalisasi pada setiap usaha perindustrian baik industri rumah tangga ataupun perusahaan. Dalam Undang-Undang no. 5 tahun 1984 yang dimaksud dengan perindustrian adalah segala kegiatan yang berkaitan dengan kegiatan industri. Industri adalah proses ekonomi yang mengolah bahan mentah, bahan baku, dan bahan setengah jadi menjadi barang jadi yang mempunyai nilai ekonomi yang tinggi. Kemudian pada pasal 2 uu no 5 tahun 1984 mengatur mengenai landasan dari pembangunan industri, dimana landasan pembangunan industri di Indonesia berlandaskan pada demokrasi ekonomi, kepercayaan pada diri sendiri, manfaat, kelestarian lingkungan hidup, dan pembangunan bangsa. Sedangkan mengenai tujuan industri diatur dalam pasal 3 dimana terdapat 8 tujuan industri diantaranya, meningkatkan kemakmuran rakyat, meningkatkan pertumbuhan ekonomi, menciptakan kemampuan dan penguasaan terhadap tehnologi yang tepat guna, meningkatnya kemampuan dari lapisan masyarakat, memperluas lapangan kerja, meningkatkan penerimaan devisa, sebagai penunjang pembangunan daerah, serta di harapkan stabilitas nasional akan terwujud. Setelah itu dalam pasal 4 uu. No.5 tahun1984 diatur mengenai masalah cabang industri. Dimana berkaitan dengan pasal 33 UUD 1945 bahwa setiap cabang indusrti dikuasai oleh Negara. Penguasaan Negara ini dimaksudkan agar tidak ada monopoli nmaun digunakakan sebagi kemantapan stabilitas nasional. Pasal 5 uu. No.5 tahun 1984 mengatur mengenai bidang usaha dan jenis indutri, dimana pemerintah mengelompokan industri dalam tiga jenis industri yakni industri kecil termasuk didalamnya keterampilan tradisional dan pengerajin yang menghasilkan benda seni. Selain industri kecil pemerintah juga menetapkan industri khusus untuk penanaman modal. Untuk pengaturan, pembinaan dan pengembangan industri 
diatur dalam pasal 7 uu no.5 tahun1984, dan mengenai izin usaha ditentukan dalam pasal 13 uu. No.5 tahun1984, serta mengenai penyampaian informasi industri diatur dalam pasal 14 uu. No 5 tahun 1984.

\section{Keuntungan Hukum Industri bagi perusahaan}

Keuntungan Hukum Industri bagi perusahaan

-Sebagai suatu pengembangan dalam mengembangkan suatu industri menjadi lebih maju dengan adanya hukum industri,dan para pelaku industri pun harus mampu menegakan hukum tersebut dalam industry karena itu suatu tanggung jawab industri tersebut dan sebagai bukti industri tersebut menjalankan hukum industri sesuai undang-undang dari pemerintah. -Para usaha industri dapat meningkatkan nilai tambah serta sumbangan yang lebih besar bagi pertumbuhan produk nasional.

-Pembinaan kerja sama antara industri kecil, industri menengah dan industri besar dapat saling bekerja sama agar masing-masing industri bisa memonopoli suatu industri yang sifatnya menguntungkan satu sama lain.

\section{Contoh Industri Pembuatan Robot}

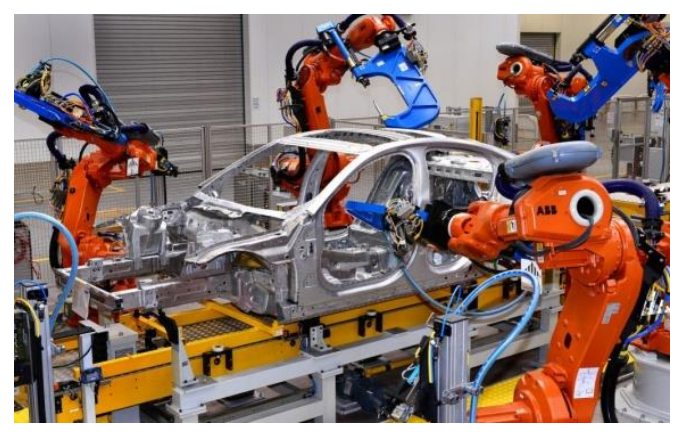

Hak Atas Kekayaan Intelektual adalah hak eksklusif yang diberikan suatu hukum atau peraturan kepada seseorang atau sekelompok orang atas karya ciptanya. Menurut UU yang telah disahkan oleh DPR-RI pada tanggal 21 Maret 1997, HaKI adalah hak-hak secara hukum yang berhubungan dengan permasalahan hasil penemuan dan kreativitas seseorang atau beberapa orang yang berhubungan dengan perlindungan permasalahan reputasi dalam bidang komersial (commercial reputation) dan tindakan / jasa dalam bidang komersial (goodwill). Dengan begitu obyek utama dari HaKI adalah karya, ciptaan, hasil buah pikiran, atau intelektualita manusia. Kata "intelektual" tercermin 
bahwa obyek kekayaan intelektual tersebut adalah kecerdasan, daya pikir, atau produk pemikiran manusia (the Creations of the Human Mind) (WIPO, 1988:3). Setiap manusia memiliki memiliki hak untuk melindungi atas karya hasil cipta, rasa dan karsa setiap individu maupun kelompok.

\section{Dasar Hukum Hak Kekayaan} Intelektual di Indonesia

Dalam penetapan HaKI tentu berdasarkan hukum-hukum yang sesuai dengan peraturan yang berlaku. Dasar-dasar hukum tersebut antara lain adalah :

- Undang-undang Nomor 7/1994 tentang Pengesahan Agreement Establishing the World Trade Organization (WTO)

- Undang-undang Nomor 10/1995 tentang Kepabeanan

- Undang-undang Nomor 12/1997 tentang Hak Cipta

- Undang-undang Nomor 14/1997 tentang Merek

- Undang-undang Nomor 13/1997 tentang Hak Paten
- Keputusan Presiden RI No. 15/1997 tentang Pengesahan Paris Convention for the Protection of Industrial Property dan Convention Establishing the World Intellectual Property Organization

- Keputusan Presiden RI No. 17/1997 tentang Pengesahan Trademark Law Treaty

- Keputusan Presiden RI No. 18/1997 tentang Pengesahan Berne Convention for the Protection of Literary and Artistic Works

- Keputusan Presiden RI No. 19/1997 tentang Pengesahan WIPO Copyrights Treaty

Berdasarkan peraturan-peraturan tersebut maka Hak atas Kekayaan Intelektual (HaKI) dapat dilaksanakan. Maka setiap individu/kelompok/organisasi yang memiliki hak atas pemikiranpemikiran kreatif mereka atas suatu karya atau produk dapat diperoleh dengan mendaftarkannya ke pihak yang melaksanakan, dalam hal ini merupakan tugas dari Direktorat Jenderal Hak-hak Atas Kekayaan Intelektual, Departemen Hukum dan 
Perundang-undangan

Republik

Indonesia.

\section{Klasifikasi Hak Atas Kekayaan Intelektual (HaKI)}

Secara umum Hak atas Kekayaan Intelektual (HaKI) terbagi dalam dua kategori, yaitu :

\section{Hak Cipta}

2. Hak Kekayaan Industri, yang meliputi :

1. Hak Paten

2. Hak Merek

3. Hak Desain Industri

4. Hak Desain Tata Letak

Sirkuit Terpadu

5. Hak Rahasia Dagang

6. Hak Indikasi

Dalam tulisan ini, penulis hanya akan membahas Hak Cipta, Hak Paten, dan Hak Merek.

\section{Hak Cipta}

Hak Cipta adalah Hak khusus bagi pencipta untuk mengumumkan ciptaannya atau memperbanyak ciptaannya. Berdasarkan Undang-
Undang Nomor 19/2002 Pasal 1 ayat 1 mengenai Hak Cipta :

Hak Cipta adalah hak eksklusif bagi Pencipta atau penerima hak untuk mengumumkan atau memperbanyak Ciptaannya atau memberikan izin untuk itu dengan tidak mengurangi pembatasan-pembatasan menurut peraturan perundang-undangan yang berlaku.

Dasar hukum Undang-undang yang mengatur hak cipta antara lain :

- UU Nomor 19 Tahun 2002 tentang Hak Cipta

- UU Nomor 6 Tahun 1982 tentang Hak Cipta (Lembaran Negara RI Tahun 1982 Nomor 15)

- UU Nomor 7 Tahun 1987 tentang Perubahan atas UU Nomor 6 Tahun 1982 tentang Hak Cipta (Lembaran Negara RI Tahun 1987 Nomor 42)

- UU Nomor 12 Tahun 1997 tentang Perubahan atas UU Nomor 6 Tahun 1982 sebagaimana telah diubah dengan UU Nomor 7 Tahun 1987 (Lembaran Negara RI Tahun 1997 Nomor 29) 


\section{Hak Kekayaan Industri}

Hak kekayaan industri adalah hak yang mengatur segala sesuatu milik perindustrian, terutama yang mengatur perlindungan hukum. Hak kekayaan industri sangat penting untuk didaftarkan oleh perusahaanperusahaan karena hal ini sangat berguna untuk melindungi kegiatan industri perusahaan dari hal-hal yang sifatnya menghancurkan seperti plagiatisme. Dengan di legalkan suatu industri dengan produk yang dihasilkan dengan begitu industri lain tidak bisa semudahnya untuk membuat produk yang sejenis/ benar-benar mirip dengan mudah. Dalam hak kekayaan industri salah satunya meliputi hak paten dan hak merek.

\section{- Hak Paten}

Menurut Undang-undang Nomor 14/2001 pasal 1 ayat 1, Hak Paten adalah hak eksklusif yang diberikan oleh Negara kepada Inventor atas hasil penemuannya di bidang teknologi, yang untuk selama waktu tertentu dalam melaksanakan sendiri penemuannya tersebut atau dengan membuat persetujuan kepada pihak lain untuk melaksanakannya. Paten hanya diberikan negara kepada penemu yang telah menemukan suatu penemuan (baru) di bidang teknologi. Yang dimaksud dengan penemuan adalah kegiatan pemecahan masalah tertentu di bidang teknologi, hal yang dimaksud berupa proses, hasil produksi, penyempurnaan dan pengembangan proses, serta penyempurnaan dan pengembangan hasil produksi.

Perlindungan hak paten dapat diberikan untuk jangka waktu 20 tahun terhitung dari filling date. Undangundang yang mengatur hak paten antara lain :

- UU Nomor 6 Tahun 1989 tentang Paten (Lembaran Negara RI Tahun 1989 Nomor 39)

- UU Nomor 13 Tahun 1997 tentang Perubahan UU Nomor 6 Tahun 1989 tentang Paten (Lembaran Negara RI Tahun 1997 Nomor 30) 
- UU Nomor 14 Tahun 2001 tentang Paten (Lembaran Negara RI Tahun 2001 Nomor 109).

\section{- Hak Merek}

Berdasarkan Undang-undang Nomor 15/2001 pasal 1 ayat 1, hak merek adalah tanda yang berupa gambar, nama, kata, huruf-huruf, angka-angka, susunan warna, atau kombinasi dari unsur-unsur tersebut yang memiliki daya pembeda dan digunakan dalam kegiatan perdagangan barang atau jasa. Merek merupakan tanda yang digunakan untuk membedakan produk/jasa tertentu dengan produk/jasa yang sejenis sehingga memiliki nilai jual dari pemberian merek tersebut. Dengan adanya pembeda dalam setiap produk/jasa sejenis yang ditawarkan, maka para costumer tentu dapat memilih produk.jasa merek apa yang akan digunakan sesuai dengan kualitas dari masing-masing produk/jasa tersebut. Merek memiliki beberapa istilah, antara lain :

\section{Merek Dagang}

Merek dagang adalah merek yang digunakan pada barang yang diperdagangkan oleh seseorang atau beberapa orang secara bersama-sama atau badan hukum untuk membedakan dengan barang-barang sejenis lainnya.

\section{Merek Jasa}

Merek jasa adalah merek yang digunakan pada jasa yang diperdagangkan oleh seseorang atau beberapa orang secara bersama-sama atau badan hukum untuk membedakan dengan jasajasa sejenis lainnya.

Selain itu terdapat pula hak atas merek, yaitu hak khusus yang diberikan negara kepada pemilik merek yang terdaftar dalam Daftar Umum Merek untuk jangka waktu tertentu, menggunakan sendiri merek tersebut atau memberi izin kepada seseorang atau beberapa orang secara bersama-sama atau badan hukum untuk menggunakannya. Dengan terdaftarnya suatu merek, maka sudah dipatenkan bahwa nama merek yang 
sama dari produk/jasa lain tidak dapat digunakan dan harus mengganti nama mereknya. Bagi pelanggaran pasal 1 tersebut, maka pemilik merek dapat mengajukan gugatan kepada pelanggar melalui Badan Hukum atas penggunaan nama merek yang memiliki kesamaan tanpa izin, gugatan dapat berupa ganti rugi dan penghentian pemakaian nama tersebut.

Selain itu pelanggaran juga dapat berujung pada pidana yang tertuang pada bab V pasal 12, yaitu setiap orang yang dengan sengaja dan tanpa hak menggunakan merek yang sama secara keseluruhan dengan merek terdaftar milik orang lain atau badan hukum lain, untuk barang atau jasa sejenis yang diproduksi dan diperdagangkan, dipidana penjara paling lama tujuh tahun dan denda paling banyak Rp100.000.000,-

Oleh karena itu, ada baiknya jika merek suatu barang/jasa untuk di hak patenkan sehingga pemilik ide atau pemikiran inovasi mengenai suatu hasil penentuan dan kreatifitas dalam pemberian nama merek suatu produk/jasa untuk dihargai dengan semestinya dengan memberikan hak merek kepada pemilik baik individu maupun kelompok organisasi (perusahaan/industri) agar dapat tetap melaksanakan kegiatan-kegiatan perekonomiannya dengan tanpa ada rasa was-was terhadap pencurian nama merek dagang/jasa tersebut.

\section{CONCLUSION}

Dapat disimpulkan bahwa HaKI adalah bagian penting dalam penghargaan dalam suatu karya dalam ilmu pengetahuan, sastra maupun seni dengan menghargai hasil karya pencipta inovasi-inovasi tersebut agar dapat diterima dan tidak dijadikan suatu hal untuk menjatuhkan hasil karya seseorang serta berguna dalam pembentukan citra dalam suatu perusahaan atau industri dalam melaksanakan kegiatan perekonomian.

Kekayaan intelektual adalah kekayaan yang timbul dari kemampuan intelektual manusia yang dapat berupa karya baik di bidang teknologi, ilmu pengetahuan, seni maupun di bidang sastra. Karya ini dihasilkan atas kemampuan intelektual melalui 
pemikiran, daya cipta dan rasa yang memerlukan curahan tenaga, waktu dan biaya untuk memperoleh suatu"produk" baru dengan landasan kegiatan penelitian atau yang sejenis. Kekayaan Intelektual (HAKI) atau Hak Milik Intelektual (HMI) atau harta intelek (di Malaysia) merupakan

padanan bahasa Inggris intellectual property right.

Adanya undang-undang yang mengatur tentang industri di indonesia sejatinya dapat mempermudah sebuah perusahaan dalam melakukan usahanya di bidang industri. Dengan adanya acuan tersebut juga akan mempermudah sebuah perusahaan baru untuk membangun usaha nya di bidang industri khususnya. Di Indonesia, walau belum sepenuhnya sempurna hukum industri telah diterapkan. Seperti hukum outsorcing dan ketenaga kerjaan yang kerap dipakai perusahaan untuk merekrut pegawai. Meski dinilai sangat menguntungkan bagi perusahaan, namun ada beberapa aspek yang justru malah merugikan para karyawannya. b. Upaya pemerintah dalam menyempurnakan rancangan undangundang perindustrian dinlai sangat baik. Penyempurnaan Undang-Undang Perindustrian bertujuan untuk membuat perangkat peraturan perundang-undangan yang sesuai dengan tuntutan zaman, yang diharapkan akan lebih mampu mendinamisasikan tumbuh-majunya industri nasional di era globalisasi ekonomi tanpa mengorbankan kepentingan nasional serta ciri budaya dan harga-diri bangsa, sebagaimana diamanatkan oleh UUD 1945, sekaligus mengakomodasi kebijakan desentralisasi dan otonomi daerah. Terlebih jika penerapan hukum industri di Indonesia terus konsisten dan tidak keluar dari jalur yang telah ditetapkan.

Hak kekayaan industri adalah hak yang mengatur segala sesuatu milik perindustrian, terutama yang mengatur perlindungan hukum. Hak kekayaan industri sangat penting untuk didaftarkan oleh perusahaanperusahaan karena hal ini sangat berguna untuk melindungi kegiatan 
industri perusahaan dari hal-hal yang sifatnya menghancurkan seperti plagiatisme. Dengan di legalkan suatu industri dengan produk yang dihasilkan dengan begitu industri lain tidak bisa semudahnya untuk membuat produk yang sejenis/ benar-benar mirip dengan mudah. Dalam hak kekayaan industri salah satunya meliputi hak paten dan hak merek.

\section{DISCUSSION}

Hasil diskusi materi ini membahas tentang Hak kekayaan industri dan Hukum industri yang ada di indonesia. Hak Kekayaan Industri adalah hak yang mengatur segala sesuatu milik perindustrian, terutama yang mengatur perlindungan hukum. Hak kekayaan industri sangat penting untuk didaftarkan oleh perusahaanperusahaan karena hal ini sangat berguna untuk melindungi kegiatan industri perusahaan dari hal-hal yang sifatnya menghancurkan seperti plagiatisme. Adanya undang-undang yang mengatur tentang industri di indonesia sejatinya dapat mempermudah sebuah perusahaan dalam melakukan usahanya di bidang industri. Dengan adanya acuan tersebut juga akan mempermudah sebuah perusahaan baru untuk membangun usaha nya di bidang industri khususnya. Di Indonesia, walau belum sepenuhnya sempurna hukum industri telah diterapkan. Seperti hukum outsorcing dan ketenaga kerjaan yang kerap dipakai perusahaan untuk merekrut pegawai. Meski dinilai sangat menguntungkan bagi perusahaan, namun ada beberapa aspek yang justru malah merugikan para karyawannya.

Di Dalam hak kekayaan industri hanyan membahas hak paten dan hak merek yang dimiliki oleh industri.

\section{Keuntungan dan Kerugian Industri} bagi Masyarakat.

Industri dalam hubungannya dengan sumber daya alam Dan lingkungan hidup serta dampak baik dan buruknya suatu industri dan keuntungan masyarakat dengan adanya suatu industri.

\section{- Keuntungan bagi masyarakat}

Dengan adanya suatu industri, masyarakat sangat terbantu dengan hal 
tersebut, karena $80 \%$ penduduk di Indonesia berprofesi sebagai pekerja dalam industri tersebut,dengan hal tersebut di indonesia sangatlah pesat bidang industri ini,selain sebagai karyawan dalam industri ditambah lagi dengan adanya hukum industri sebagai pengatur didalam industri tersebut,dengan adanya hukum industri para karyawan mendapat hak nya sesuai dengan hukum industri yang ada dan para karyawan dan masyarakat yang terbantu dengan adanya hukum industri ini harus dapat mengikuti hukum tersebut.

\section{- Kerugian bagi masyarakat}

Dengan adanya hukum industri bukan berarti para karyawan dan masyarakat tidak mengalami kerugian,para pelaku industri seringkali semena-mena dengan adanya hukum tersebut maka para pelaku industri seringkali tidak mematuhi aturan yang diberikan oleh hukum industri,sehingga para karyawan yang berkecimbung didalam industri tersebut seringkali menjadi imbas dari para pelaku industri, bertindak seenaknya kepada para karyawan dan kurangnya perlakuan yang layak bagi para masyarakat atau karyawan. 


\section{E. REFERENCE}

[1] O. M. Febriani and A. S. Putra, "Sistem Informasi Monitoring Inventori Barang Pada Balai Riset Standardisasi Industri Bandar Lampung," J. Inform., vol. 13, no. 1, pp. 90-98, 2014.

[2] A. S. Putra, "Paperplain: Execution Fundamental Create Application With Borland Delphi 7.0 University Of Mitra Indonesia," 2018.

[3] A. S. Putra, "2018 Artikel Struktur Data, Audit Dan Jaringan Komputer," 2018.

[4] A. S. Putra, "ALIAS MANAGER USED IN DATABASE DESKTOP STUDI CASE DB DEMOS."

[5] A. S. Putra, "COMPREHENSIVE SET OF PROFESSIONAL FOR DISTRIBUTE COMPUTING."

[6] A. S. Putra, "DATA ORIENTED RECOGNITION IN BORLAND DELPHI 7.0."

[7] A. S. Putra, "EMBARCADERO DELPHI XE 2 IN GPUPOWERED FIREMONKEY APPLICATION."

[8] A. S. Putra, "HAK ATAS KEKAYAAN INTELEKTUAL DALAM DUNIA TEKNOLOGY BERBASIS REVOLUSI INDUSTRI 4.0."

[9] A. S. Putra, "IMPLEMENTASI PERATURAN PERUNDANGAN UU. NO 31 TAHUN 2000 TENTANG DESAIN INDUSTRI BERBASIS INFORMATION TECHNOLOGY."

[10] A

S. Putra,
"IMPLEMENTATION OF PARADOX DBASE."

[11]

A. S. Putra, "IMPLEMENTATION OF TRADE SECRET CASE STUDY SAMSUNG MOBILE PHONE."

[12] A. S. Putra, "IMPLEMENTATION

PATENT FOR APPLICATION WEB BASED CASE STUDI WWW. PUBLIKLAMPUNG. COM."

[13] A. Putra "IMPLEMENTATION SYSTEM FIRST TO INVENT IN DIGITALLY INDUSTRY."

[14] A. S. Putra, "MANUAL REPORT \& INTEGRATED DEVELOPMENT

ENVIRONMENT BORLAND DELPHI 7.0."

[15] A. S. Putra, "PATENT AS RELEVAN SUPPORT RESEARCH."

[16] A. S. Putra, "PATENT FOR RESEARCH STUDY CASE OF APPLE. Inc."

[17] A. S. Putra, "PATENT PROTECTION FOR APPLICATION INVENT."

[18] A. S. Putra, "QUICK REPORT IN PROPERTY PROGRAMMING."

[19] A. S. Putra, "REVIEW CIRCUIT LAYOUT COMPONENT

REQUIREMENT ON ASUS NOTEBOOK."

[20] A. S. Putra, "REVIEW TRADEMARK PATENT FOR INDUSTRIAL TECHNOLOGY BASED 4.0."

[21] A. S. Putra, "TOOLBAR COMPONENT PALLETTE IN 
OBJECT

ORIENTED

PROGRAMMING."

[22] A. S. Putra, "WORKING DIRECTORY SET FOR PARADOX 7."

[23] A. S. Putra, "ZQUERY CONNECTION IMPLEMENTED

PROGRAMMING

STUDI CASE PT. BANK BCA Tbk."

[24] A. S. Putra, D. R. Aryanti, and I. Hartati, "Metode SAW (Simple Additive Weighting) sebagai Sistem Pendukung Keputusan Guru Berprestasi (Studi Kasus: SMK Global Surya)," in Prosiding Seminar Nasional Darmajaya, 2018, vol. 1, no. 1, pp. 85-97.

[25] A. S. Putra and O. M. Febriani, "Knowledge Management Online Application in PDAM Lampung Province," in Prosiding International conference on Information Technology and Business (ICITB), 2018, pp. 181-187.

[26] A. S. Putra, O. M. Febriani, and B. Bachry, "Implementasi Genetic Fuzzy System Untuk Mengidentifikasi Hasil Curian Kendaraan Bermotor Di Polda Lampung," SIMADA (Jurnal Sist. Inf. dan Manaj. Basis Data), vol. 1, no. 1, pp. 21-30, 2018.

[27] A. S. Putra, H. Sukri, and K. Zuhri, "Sistem Monitoring Realtime Jaringan Irigasi Desa (JIDES) Dengan Konsep Jaringan Sensor Nirkabel," IJEIS (Indonesian J. Electron. Instrum. Syst., vol. 8, no. 2, pp. 221-232.

[28] D. P. Sari, O. M. Febriani, and
A. S. Putra, "Perancangan Sistem Informasi SDM Berprestasi pada SD Global Surya," in Prosiding Seminar Nasional Darmajaya, 2018, vol. 1, no. 1, pp. 289-294. 